\title{
Identity in Interaction: Language Practices and Attitudes of the Newest Ukrainian Diaspora in Canada $^{1}$
}

\author{
Alla Nedashkivska \\ University of Alberta
}

"The fact that languages - and language ideologies - are anything but neutral is
especially visible in multilingual societies where some languages and identity
options are, in unforgettable Orwellian words, 'more equal than others."”

(Pavlenko and Blackledge 3)

\begin{abstract}
The present study focuses on processes and transformations in language practices and attitudes in the newest wave of the Ukrainian diaspora in Canada, notably following the 2014 Revolution of Dignity in Ukraine. Specifically, multilingual language practices in social media and in off-line environments (Ukrainian, Russian, English), participants' beliefs about language(s), and participants' views about the language question are analyzed. The analysis also relates the speakers' practices and beliefs to issues of identity construction and negotiation that are observable in the context of this diasporic community.

The socio-cultural approach to studying identity in interaction developed by Bucholtz and Hall ("Identity") is used as the premise for the main theoretical foundation of the study. In this framework, identity is defined as "the social positioning of self and other" and is best studied at an interactional level because it is in interaction that language resources gain social meaning (Bucholtz and Hall, "Identity," 586).

Basing the analysis on the "discourse-centered online ethnography" approach (Dailey-0'Cain 54), the data were collected from two sources: one social media communication network and in-person interviews with this network's members. Therefore, the analysis combines a study of multilingual interaction in social media communication with an investigation of how participants report on their language practices overall, including their views about the language question. The domains of language and discourse about language constitute the organizational core of the analysis, as both contribute to the discussion of language attitudes and speakers' shaping and reshaping of their identities. The domain of language incorporates a study of code-switching, including language choice and language practices of the participants, observed or reported. A discourse about language focuses on the
\end{abstract}

\footnotetext{
1 This article is a part of the Nationalities, Culture and Language Policies Cluster, Research Initiative on Democratic Reforms in Ukraine (RIDRU) project: http://ridru.artsrn.ualberta.ca/
} 
importance of the language question to the participants, their positioning toward language(s), and/or language practices, as well as participants' associations with and disassociations from particular languages, concepts, or entities. The discussion relates the functions of different languages in the studied community to larger questions of the diaspora studied. The prominence of "real" and "ideal" codeswitching phenomena are highlighted. The code-switching, along with language choice and language practices, as well as discourse about language, are all shown to be resources employed by the speakers to position themselves in specific associations or disassociations. Overall, the study investigates the newest Ukrainian diasporic community, demonstrating how language practices in human interaction display and construct identity(ies) and signal participants' negotiations of their own identities and those of others.

Keywords: identity, interaction, language practices, language attitudes, diaspora, Ukrainian, Canada.

\section{INTRODUCTION AND BACKGROUND}

U kraine, Ukrainians, and Ukrainian communities around the world are increasingly visible due to the recent political and military turmoil in Ukraine. Russia's 2014 annexation of Crimea and ongoing invasion of parts of Southeastern Ukraine have had a profound impact on both Ukraine's citizens and various Ukrainian communities. Momentous political, economic, sociological, psychological, and also linguistic identity transformations have been taking place. Since the Maidan events of 2014, known as the Revolution of Dignity, 2 scholars note significant transformations in Ukraine with respect to national identity (Kulyk, "Ukrainian Nationalism"; "National Identity"), the linguistic landscape and identity (Cheskin), language policy and governance (Goodman), language attitudes (Kulyk, "Language Ideologies"), as well as shifts in the language itself (Bilaniuk). Interestingly, some of these same processes are taking place beyond Ukraine's borders, within various Ukrainian communities around the globe (Seals). The present study focuses on processes and transformations in language practices and attitudes that are observable in one Ukrainian community in Canada. It focuses specifically on the newest Ukrainian diaspora in Canada, the wave of migration that was triggered mainly by political and military realities that have faced Ukraine since 2014 .

\footnotetext{
2 On November 21, 2013, the protest movements in Ukraine began, following President Viktor Ianukovych's delay in signing the European Union Association Agreement. These movements, the Euromaidan, evolved into mass protests against the authoritarian government of the time.
} 


\section{UKRAINIAN DIASPORA IN CANADA: AN OVERVIEW AND SCHOLARSHIP}

The Ukrainian diaspora in Canada has a long history. Five waves of Ukrainian immigration to Canada have been formally delineated; the sixth, the most recent wave, is the focus of this article. Each Ukrainian immigration wave came to Canada under quite different circumstances. The first wave dates from the early 1890 s to 1914 , when many Ukrainians, especially those from Western Ukraine, came to Canada due to an offer of farmland. These were settlers in the true sense who cleared the land (see Martynowych; Lynn; Luciuk and Hryniuk).

The second wave of Ukrainians, also mostly from Western Ukraine, dates to the interwar period, 1919-39. This wave came to Canada as labourers in agriculture, various industries, and resource extraction:

These immigrants were coming from areas where they were minorities due to the new political partitioning [because of the first world war], and particularly in Poland and Romania, acute nationalist sentiments resulted in cultural and economic oppression directed at the Ukrainian population there. (Lynn 15)

The third wave of Ukrainian immigrants to Canada, 1946-61, comprised post-World War II immigrants and refugees from all parts of Ukraine. These people were, to a large extent, educated professionals and included many from the intelligentsia. They also contributed greatly to the flourishing of Ukrainian communities in Canada. This third wave of immigrants

not only added to the number of Ukrainians in Canada and strengthened the community in terms of population and occupational diversity, but also brought a 'linguistic rejuvenation' to the Ukrainian population. As few of these immigrants spoke fluent English or French, they actively looked for places where they could communicate in Ukrainian, resulting in larger concentrations of Ukrainians and of the Ukrainian language and giving Ukrainian language a higher external profile. (Luciuk and Hryniuk; Lynn 20)

Aspirations to preserve the Ukrainian language, which was suppressed in Ukraine, were visible. ${ }^{3}$

A fourth wave of Ukrainian immigrants to Canada, often overlooked, was made up of people from Ukrainian communities outside of Ukraine, but from within the Eastern Bloc. This smaller group, which immigrated throughout the 1980s and into the 1990s, was composed of people primarily from central European countries such as Poland and the former Yugoslavia, in

\footnotetext{
${ }^{3}$ For definitions of the first three waves of Ukrainian immigration to Canada, see Kaye and also Petryshyn ("Toward a Framework").
} 
which Ukrainians lived as minorities. According to Petryshyn, this wave formed a particular type of Ukrainian identity, distinct from other waves ("Is There a Need").

The fifth wave of Ukrainian immigrants to Canada followed Ukraine's independence in 1991. According to Petryshyn, the emigration from Ukraine in the 1990s - when Ukraine was still something of a totalitarian society in which Ukrainians constituted a majority of the native population-allows for the classification of this wave as the fifth wave ("Is There a Need"). "Ukraine's Independence is of great importance and significance" to this "wave of immigration and for Ukrainians in Canada; it had, and has, meaningful, influential and far-reaching effects and implications for politics, culture, and the relationship between Ukraine and its diaspora here" (Lynn 23). ${ }^{4}$ As Lynn notes, the representatives of this wave

were coming to Canada from a vastly different Ukraine, and this transformation of Ukraine would mean a transformation of its people. The events from 1991-2012 in Ukraine have raised new considerations for questions of identity-construction and discourse of post-Soviet Ukrainian immigrants to Canada. (25)

I would also argue that this fifth wave lasted to 2014, when Ukraine's political landscape changed quite radically again.

The most recent wave of Ukrainian immigrants to Canada, the sixth wave, may be considered to have started in the period immediately following the 2014 Maidan revolution, which shook Ukrainian society and provoked major shifts in the country and its people. The Russian annexation of Crimea and invasion of eastern parts of Ukraine triggered changes in the patterns of migration in Ukraine and from Ukraine. ${ }^{5}$ With respect to Canada, this last wave, not yet clearly labelled in scholarship as a separate wave, constitutes the focus of the present study.

Scholarship on the Ukrainian diaspora in Canada is substantial and solid. The studies have been considered from a broad spectrum of perspectives,

\footnotetext{
${ }^{4}$ Lynn considers the 1991-2012 immigration to Canada to be the fourth wave. I agree with Petryshyn, who proposes to separate the immigration from the 1980s to the 1990s as discussed above (Petryshyn, "Is There a Need"). For the purpose of this study, I consider the period 1991-2014 as the fifth wave.

5 Ukrainian media sources report on high levels of emigration from Ukraine to various countries of the EU and North America since 2014. Some note that in the 1990s, Ukraine experienced a high number of emigrants, reaching a peak in 2000. From 2000 until 2013, the numbers of those leaving Ukraine dropped visibly. However, since 2014, when the war began, the numbers of those who left Ukraine and those who are considering leaving Ukraine are escalating ("Nabrydlo"). In 201415 , over one million Ukrainians left their country (Vesela).
} 
including historic, familial, folkloric, educational, and religious. Linguistic questions, however, have garnered far less attention. Moreover, existing studies in the field address the three first waves of Ukrainian diasporas up to the 1960s (Luciuk and Hryniuk; Hryniuk and Luciuk 3; Hinther and Mochoruk), with only a few inquiries into the latest waves of the 1980s and since the 1990s (Petryshyn, "Is There a Need"), or the fifth wave of postSoviet Ukrainian immigrants, which is addressed by Lynn. ${ }^{6}$ In her masters' thesis, Lynn focuses on the relationships of fifth wave immigrants with the established diaspora, and on linguistic, social, and cultural issues. The newest, sixth, post-Maidan wave, is fairly recent and thus understudied. It deserves investigation, especially in light of the turbulent political events that Ukraine continues to experience and which had a direct impact on this group of immigrants.

Of particular interest is the source of the sixth migration wave, which has diverged from the traditional Western or Central Ukraine; now many Canadian Ukrainian immigrants come from Eastern Ukraine or Crimea. ${ }^{7}$ Another factor important to note are differences in the linguistics practices, and the presence of Russian-speaking Ukrainians in particular, in this sixth immigration wave. In the past five waves of migration to Canada, Russianspeaking Ukrainians tended to not participate in the community life of the Ukrainian diaspora, possibly because this community tended to be Ukrainian-language focused and was unaccepting of them, or because they felt uncomfortable in it due to their own preference for the Russian language. To my knowledge, the issue related to Russian-speaking Ukrainians has not been adequately addressed and deserves a separate investigation.

The present project examines the sixth wave of Ukrainian diaspora in Canada, focusing on language practices of this community as they relate to language use, language attitudes, and how these factors interact with questions of identity. The study analyzes social media texts and participant interviews that demonstrate language practices of Ukrainian immigrants to Canada in both online and off-line spaces. Both contexts allow for the analysis of processes and shifts in the public discourse of the newest wave of Ukrainian diaspora. Social media texts and interview data collected from these immigrants are viewed as cultural constructs, portraying everyday social and language practices of this diasporic community. Both types of data contain social meanings, attitudes, ideologies, and values, and communicate contemporary identity shifts and transformations. The second objective is to investigate the relationship between language practices and identity

\footnotetext{
${ }^{6}$ Lynn labels this immigration group as the fourth wave.

7 These observations, partially based on data received for the present study, will have to be verified by researchers of respective disciplines. With respect to changes in the structure and demographics of emigration from Ukraine since 2014, see also Vesela.
} 
negotiation in the diasporic space of the Ukrainian community in Canada. The focus is on multilingual interactions in social media and in everyday practice, which both present platforms for identity construction online and in physical space. In sum, the study investigates the newest Ukrainian diasporic community and analyzes language practices in interaction, in which identity(ies) are displayed and constructed, and in which speakers negotiate their own identities and those of others.

\section{THEORETICAL FRAMEWORK AND TERMINOLOGY}

\section{DiASPORIC COMMUNiTIES AND SOCIAL MEDIA}

Communication technologies have always played an important role in the maintenance of relationships between diasporic communities and the homeland (Androutsopoulos, "Multilingualism, Diaspora"; Karim). Beginning with radio, television, and video, technology has progressed to electronic communication via e-mail, chat channels, newsgroups, mailing lists, and social media networks, allowing diasporic communities to create "virtual neighborhoods of international electronic communication" (Appadurai 195). Such communication technologies provide "spaces for user interaction which 'offer a safe and comfortable place where people of particular ethnic groups can digitally 'hand out' and share their stories'” (Mitra, qtd. in Androutsopoulos, "Multilingualism, Diaspora," 520). According to Tsaliki,

electronic communities are far from dehumanized formations . . . cyberspace is perceived and experienced as a place where people share a sense of belonging, forms of expression, meanings and emotions, language, memories and rules of conduct which are as genuine as their real-life counterparts. (176)

The social networks of the diaspora communities are both local and transnational, allowing participants to explore questions of identity through a variety of practices or through diverse frames.

Facebook, one of the world's most powerful social network services, ${ }^{8}$ is not only a space for self- and other-expression, self- and other-presentation, and self- and other-promotion, it is also a space for the creation and development of virtual communities that are connected via certain vectors

\footnotetext{
${ }^{8}$ According to Internet World Stats, as of June 30, 2017, there are 1,978,243,530 Facebook subscribers in the world, which is over one fourth of the entire world population ("Facebook Users").
} 
and whose trajectories intersect along certain lines of experience and background. In recent years, Facebook has become a popular focus of research into new media technologies (van Dijck, "Facebook" and "You Have"), social and behavioural sciences (Valenzuela), communication and literary studies (Das and Pavlíčková), political and social sciences (Kulyk, "Ukrainian Nationalism"; "Language Ideologies"), linguistics (Androutsopoulos, "Networked Multilingualism"), and other disciplines in the humanities and social sciences.

With respect to Ukraine, one such example is the research conducted by Kozachenko ("Retelling"), who, following the Maidan revolution, has been using sociological perspectives to study various online groups and social media networks. Within the context of the current war in Ukraine, Kozachenko analyzes questions of national belonging by anti-Maidan representatives and their supporters. ${ }^{9}$ In his study, Kozachenko outlines various ideological paradigms and how they converge within online communities and networks. He demonstrates how the anti-Maidan community "constructed and performed online a 'supra-national' identity that is based on the eclectic usage of 'Sovietophile' and Russophile symbols, myths, and narratives" ("Retelling," 156). In sum, Kozachenko shows how social media networks can act as weapons in national projects.

From political and social sciences perspectives, Kulyk ("Ukrainian Nationalism") uses post-Maidan Facebook posts to investigate Ukrainian nationalism, ideology, and identity questions. Kulyk notes that people articulate their national identities in Facebook posts and that "both ideologies and sentiments are nowadays routinely expressed and recorded" ("Ukrainian Nationalism," 95-96). Kulyk's analysis of Facebook posts reveals that Russian aggression in Ukraine changed Ukrainian patriotism from a variety of perspectives. Importantly, it "has expanded impressively on the mass level to include segments of the population that had previously been rather ambivalent about their national belonging and attachment" ("Ukrainian Nationalism," 119). Kulyk notes that, post-Maidan, some people began to feel more Ukrainian. And what is more important, they acted on these feelings ("Ukrainian Nationalism," 119). Facebook data demonstrate that as a direct result of foreign invasion, Ukrainians began to display sentiments that were not pro-Russian, often openly anti-Russian, and aimed primarily at Russia's political regime. Interestingly, this alienation from the Russian regime does not necessarily translate into an alienation from the Russian language. According to Kulyk, the new political situation resulted in

\footnotetext{
9 The "anti-Maidan" movement emerged during the Maidan revolution, November 2013-February 2014. Initially presented as a legitimate people's movement in support of the Ianukovych regime, the movement largely dissipated following the start of open aggression on Ukraine by Russia.
} 
new boundaries between Ukrainians and Russians, with borders being political rather than ethnolinguistic ("Ukrainian Nationalism," 119-21). Kulyk concludes that political events in post-Maidan Ukraine "contribut[ed] to the rise of inclusivity of Ukrainian nationalism," its civic nature, and the inclusiveness of Ukrainian identity, demonstrating how questions of identity resurfaced and gained new meanings in the mainland Ukrainian community (“Ukrainian Nationalism," 121).

\section{DIASPORA}

Research on diasporas focuses on concepts of displacement, dispersal, migrancy, belonging, a desire or possibility of "return," and the relationship between the diaspora community and a particular country or nation, typically the homeland (Angouri). According to Shuval,

The term diaspora . . . encompasses a motley array of groups such as political refugees, alien residents, guest workers, immigrants, expellees, ethnic and racial minorities, and overseas communities. It is used increasingly by displaced persons who feel, maintain, invent or revive a connection with a prior homeland. Concepts of diaspora include a history of dispersal, myths/memories of homeland, alienation in the host country, desire for eventual return-which can be ambivalent, eschatological or utopian-ongoing support of the homeland and a collective identity defined by the above relationship. (41)

In recent scholarship, the dynamicity and fluidity of diasporas continue to be underscored (Mavroudi; Tsagarousianou). Diaspora researchers view such a community as an ethnic minority with feelings of "difference and awareness of its marginal status within a host society; its desire to maintain links with the homeland, and to resist complete assimilation"; and as a community in which a constant negotiation between identities and cultures is taking place (Androutsopoulos, "Multilingualism, Diaspora," 520). Scholars also discuss the hybridity of diaspora. Hybridity is viewed as "the process of cultural mixing where the diasporic arrivals adopt aspects of the host culture and reword, reform and reconfigure this in production of a new hybrid culture or 'hybrid identities'” (Chambers, qtd. in Virinder et al. 71). As the questions of membership and belonging to diaspora are complex, definitions range from all inclusive membership-in which membership embraces "virtually everyone who can be claimed as part of a particular group or population, usually by virtue of ancestry" - to membership based on various types of migration or groupings, such as "labour diasporas, imperial diasporas, trade diasporas and deterritorialized diasporas" (Bartram et al. 51; 50-51). Some scholars propose to discuss diaspora not so 
much in terms of membership, but rather as "a category of practice in which people make claims, form projects, mobilize for those projects, and appeal to loyalties to advance those claims and projects" (Brubaker, qtd. in Bartram et al. 51). The latter definition informs the present analysis.

In this study, I view diaspora as a hybrid migrant community in which participants (re-)construct their personal profiles and those of others, including that of the community, and in which (re-)negotiations between identities and cultures are taking place. In addition, diaspora is a dynamic network that, due to current technological innovations and communication technologies, can live in or have close ties to both the homeland and the receiving country (Kozachenko, "ICT," 8).

\section{LANGUAGE ATTITUDES}

Research into attitudes toward languages or language varieties has been an important focus in linguistics for many decades. As Dailey-0'Cain notes, "attitudes cannot be directly observed .... Attitudes are internal, in other words-they are thoughts and ideas in people's minds that are largely hidden away unless externalized in some way-and sometimes they are not externalized at all" (136). Dailey-0'Cain also states that attitudes are studied through their expression and "[t]his expression of attitudes . . . always occurs within some kind of context (. . . a talk show . . . a questionnaire, an interview or an informal conversation ...) and the wider social context (e.g. demographic characteristics of the participants in the expression that might have an influence on it)" (136-37). The wider societal context allows for "understanding the relationship between language attitudes and language ideologies" (Dailey-0'Cain 137).

Language attitudes in the present study are analyzed through their expression in the context of social media communication and participants' reports regarding their language practices in everyday life and their beliefs about language.

\section{CODE-SWITCHING}

Code-switching is viewed as "a social phenomenon with specific motivations and functions" (Nedashkivska 355) and is understood as "instances of language alternation or language choice" (Heller, "Code-Switching," 159). According to Heller, code-switching may be viewed as a strategy for "playing the game of social life," in which "[l] anguage practices are inherently political insofar as they are among the ways individuals have at their disposal of 
gaining access to the production, distribution and consumption of symbolic and material resources, that is, insofar as language forms part of processes of power" ("Code-Switching," 161). In Heller's terms, code-switching is "a strategy in both situations of certainty and of uncertainty, that is, (a) in situations where there are clear unmarked conventions of language choice; and (b) in situations where no such conventions may exist OR where there may be competing conventions" (Codeswitching 81). According to Heller, code-switching "[f]or the analyst . . . acts as a flag, it signals that ... people are drawing on their linguistic resources in some way which will have an effect both on them and on others. They are using language to take action in a complex world, to react to their experience and to create it anew" ("CodeSwitching," 164). In the present analysis, code-switching is considered to be an important linguistic strategy that contributes to participants' signals of belonging, identity claims, and negotiations.

\section{IDENTITY}

The concept of identity enjoys a great deal of scholarly attention and continues to be defined and redefined from multiple perspectives and in diverse theoretical foundations and disciplines. With respect to multilingual contexts, Pavlenko and Blackledge offer a comprehensive review of approaches to the concept of "identity," focusing on the socio-psychological (second language learning and language use) and the interactional sociolinguistic (code-switching and language choice). They propose a poststructuralist framework that allows them to "examine and explain negotiation of identities as situated within larger socioeconomic, sociohistoric, and sociopolitical processes" (Pavlenko and Blackledge 4). They note that this "framework is well equipped to capture the complexity of postmodern societies, where language may not only be 'markers of identity' but also sites of resistance, empowerment, solidarity, or discrimination" (304). Relevant to the present study is Pavlenko and Blackledge's claim

that individuals are agentive beings who are constantly in search of new social and linguistic resources which allow them to resist identities that position them in undesirable ways, produce new identities, and assign alternative meanings to the links between identities and linguistic varieties. (27)

Norris studies production and negotiation of identity from a multimodal interactional analysis perspective, and this theory informs the present analysis. In her framework, 
identity is embedded and (co)produced in ... the social-time-place of a particular social actor together with other social actors, together with and within the historical time, together with cultural tools, and together with and within the environment.

Social-time-place of a particular social actor has the following meaning: the social actor lives within particular social structures, within a particular historical moment, and in a particular place-all of these, the social structures, the historical time, and the particular place-bring with it affordances and constraints for particular identity production. Thus, a social actor's identity is mediated by and mediates the social-time-place in actions that are performed and that are understood by other social actors as practices or parts of practices of that social-time-place in which the actions are performed. (Norris 30-31)

Principles that view identity as being constructed in social interaction are of particular importance to the objectives of this study. The sociocultural approach to studying questions of identity in interaction proposed by Bucholtz and Hall ("Identity") is used to build a theoretical foundation for this study. According to Bucholtz and Hall, "[i]dentity is the social positioning of self and other" ("Identity," 586). In their framework, Bucholtz and Hall note the importance of studying identity at an interactional level because it is in interaction that language resources gain social meaning ("Identity," 586). Bucholtz and Hall analyze identity based on five principles:

(i) emergence, which suggests that "[i]dentity is best viewed as the emergent product rather than the pre-existing source of linguistic and other semiotic practices and therefore as fundamentally a social and cultural phenomenon" ("Identity," 588);

(ii) positionality, which means that "[i]dentities encompass (a) macro-level demographic categories; (b) local, ethnographically specific cultural positions; and (c) temporary and interactionally specific stances and participant roles" ("Identity," 592);

(iii) indexicality, which links identity to linguistic elements or indexes such as labels, implicatures, stances, styles, or linguistic structures and systems ("Identity," 585, 594);

(iv) relationality, meaning that "[i]dentities are intersubjectively constructed through several, often overlapping, complementary relations, including similarity/difference, genuineness/artifice, and authority/delegitimacy" ("Identity," 598);

(v) partialness, "identity may be in part intentional, in part habitual and less than fully conscious, in part an outcome of interactional 
negotiation, in part a construct of others' perceptions and representations, and in part an outcome of larger ideological processes and structures" ("Identity," 585).

The present analysis is driven by data, while maintaining an interactional approach to identity, based on the five categories outlined above. Concepts and their categorization are not pre-established but emerge from the data collected. In one of their later studies, Bucholtz and Hall note that "it is our data, not our theories, that are our best guide to how language is used to create local social worlds" ("Finding," 161). Therefore, it is by analyzing the data that our categories for studying identity in interaction are established, analyzed and discussed below.

\section{METHODOLOGY AND PROCEDURES}

The present analysis is situated within what Dailey-0'Cain refers to as "a discourse-centred online ethnography, which combines the analysis of data drawn from a social media community with in-person interviews with community members" (54). The data are collected from two sources. The first set is gathered from one Ukrainian social network, originated and administered in one city in Canada. This network, as of September 2017, boasted around 1,800 members. ${ }^{10}$ This group's main goal, as stated on the site and here paraphrased, is to encourage and facilitate friendship and active engagement of Ukrainians in this particular city and province, share information and assist newcomers with advice, and have discussions about Ukrainian cultural life in the relevant province and Canada. One hundred and ten posts between December 1, 2015, and January 19, 2016, are considered in the analysis. One hundred and sixteen screen shots were taken of the page, covering each post and its accompanying comments (when available) during the same time period. These screen shots were further divided into "posts" and "discussions" by month. The posts category comprised verbal and/or visual texts such as announcements, inquiries, and articles shared with the online community. These texts did not yield any responses. The discussions category involved an initial post, plus response(s) to it. Discussions were less numerous than postings. There were 50 postings and nine discussions in

\footnotetext{
${ }^{10}$ Membership in this group is not restricted along any variables but needs to be approved by group administrators. Participants are asked to follow specific rules of politeness and participate within the parameters of this group's main goals. Participants may be banned from the group, based on mutual consent of administrators, for not adhering to the rules of this group.
} 
December 1-31, 2015, and 39 postings and twelve discussions in January 119, 2016. ${ }^{11}$

The choice of the time period for the data collection is justified by a number of factors. First, the above-mentioned dates include Christmas celebrations according to both the Julian and the Gregorian calendars. Second, it was speculated that the selected time-frame would allow for a certain variety of posts in the group, i.e., not exclusively political or inspired by current events in Ukraine, but also cultural events dedicated to Christmas and the holiday season, travel, and various celebratory activities. With an average of two postings per day, it was calculated that limiting the time period to fifty days would yield a manageable data pool of approximately one hundred posts, which creates a reliable data set for the analysis. Overall, the texts identified for the analysis, verbal and visual, constitute examples of public discourse on issues that are of interest or concern to the diaspora community.

The second set of data is comprised of ten interviews conducted with recent immigrants, who are also members of the social network studied. ${ }^{12}$ These interviews were conducted in the summer of 2016 by a trained research assistant fluent in Ukrainian, Russian, and English. Out of ten participants, as their first language and/or the language in which they are most proficient, four participants (one male: Taras; and three females: Ksenia, Alina, and Katia) noted Russian and six participants (two males: Sashko and Iaroslav; and four females: Bohdana, Halyna, Liuba, and Natalia) declared Ukrainian. ${ }^{13}$ All participants were in their mid-twenties to midthirties, six were married and four unmarried. Participants were given a choice of Ukrainian, Russian, or English to carry out their interview. All participants chose either Ukrainian or Russian, declaring their choice to be the language in which they are most proficient. The interviews were semistructured, and were allowed to evolve around questions that focused on: demographic information about the participant, the language practiced by the participant in various contexts, the importance to the participant of the language question in his or her everyday life, the participant's cultural and linguistic experiences in Canada, the participant's quality of life in the diaspora, and the participant's connection to Ukraine (see the Appendix for a full list of leading interview questions).

\footnotetext{
11 One discussion may encompass up to three screen shots. Similarly, one screenshot may contain up to two posts due to the difference in the amount of written and/or illustrative information represented by each category.

12 This study was conducted according to the ethics regulations of the University of Alberta and approved by the HERO system at the University of Alberta.

${ }^{13}$ All names are pseudonyms created to protect the identity of participants.
} 
The semi-structured format of the interview allowed to focus on particular questions that would be similar for all participants. But it also permitted an exploration of other areas deemed important by the interviewee and interviewer. Interview data were used to support and extend analysis of the data set from the social media network.

\section{ANALYSIS}

The present analysis combines a study of social media communications and an investigation of how participants report on their language practices in everyday life. This includes their views about the broader language question, and its place and relevance in their lives, that is, their language attitudes. The analysis also relates the speakers' practices and beliefs to larger issues of identity construction and negotiation that are observable in the context of this one diasporic community.

The analysis of social media posts, as well as the interviews studied, allows for establishing two principal domains in which identity in interaction surfaces: the language and the discourse about the language. These two domains constitute the organizational core of the present analysis, as both relate to the discussion of language attitudes and speakers' shaping and reshaping of their own identities.

The domain of language includes code-switching, ${ }^{14}$ language choice, and the language practices of participants, observed or reported. Code-switching and language choice have been traditionally considered important linguistic means of negotiating identities (Auer; Heller, Codeswitching). These linguistic practices are viewed as markers of identity negotiations in distinct interactional contexts. The discourse about language is primarily concerned with the importance of the language question to the participants and in the studied community; with participants' expressions about language(s) (that is their language attitudes); and with participants' created and/or negotiated associations and disassociations (distancing) from particular language(s), concepts or entities. Discourse about language and speakers' positioning toward language(s) and/or language practices are considered markers that demonstrate ways in which speakers adapt for "self"- and "other"- representations. These markers contribute to our understanding of identity production and negotiation in the studied diasporic community.

\footnotetext{
14 I use the term "code-switching" throughout the discussion, albeit in some instances one may argue that the term "crossing" is more appropriate. "Crossing" is defined as "the use of language varieties associated with social or ethnic groups that the speaker doesn't normally 'belong' to" (Rampton 14).
} 


\section{LANGUAGE}

While analyzing the domain of language, Heller's ("The Politics") and Pavlenko and Blackledge's principles were followed:

any analysis of language practices needs to examine how conventions of language choice and use are created, maintained, and changed, to see how language ideologies legitimize and validate particular practices, and to understand real-world consequences these practices have in people's lives. Methodologically, this implies that code-switching needs to be examined not as a unique phenomenon but as a part of a range of linguistic practices which people employ to achieve their goals and to challenge symbolic domination. (Pavlenko and Blackledge 12; see also Heller, "The Politics")

The analysis reveals that in the social media posts studied, three languages are used by participants: Ukrainian, English, and Russian. ${ }^{15}$ In the majority of posts and discussions, the language of choice is Ukrainian, with an occasional Ukrainian-English code-switching, as illustrated by examples 1 and 2: 16

1. (A) [U] ${ }^{17}$ Friends, please advise on a good dentist...

(B) [U] I am surprised that no one has suggested the University dentistry. Everything is much cheaper.

(C) [U] I, once, had my hair colour done by a student in cosmetology...

[E] no thanks...

[U] I would not take my teeth to a student...

2. (A) [U] Hello everyone ... Perhaps anyone could suggest something with respect to work in [city name]?

(B) $[\mathbf{U} /$ transliteration $]$ Hello, Olha.

[E] I would be happy to share my experiences with you ... What are your long-term goals? Do you have Canadian education ... Please message me, we can chat.

In example 1, the conversation between the three participants is in Ukrainian. Speaker C writes in Ukrainian; however, the intra-sentential

\footnotetext{
${ }^{15}$ Although Canada has two official languages, English and French, the community studied is in a predominantly English-speaking part of the country, and no instances of French were found in the social media posts.

16 In examples, personal names have been changed to ensure anonymity of the participants.

${ }_{17}$ All examples are presented in English, as this is the practice followed by EWJUS. The original language of interaction is indicated as follows: [U] - Ukrainian, [R] Russian, [E] - English. All translations are mine.
} 
switch to English, "no thanks," suggests this speaker is local and knows the local habitat. In example 2, speaker A writes her request in Ukrainian. Speaker B uses English almost exclusively, and by choosing this language the speaker demonstrates his/her knowledge of English and perhaps an established status in the local community as an "expert," who could help out in the professional sphere. It is interesting that in example 2 , speaker B uses Ukrainian in an initial greeting, including the Vocative case in the address form, an indication of standard Ukrainian. This code-switching to Ukrainian in a greeting legitimizes the Ukrainianness of the speaker, and perhaps also a perceived closeness with the addressee, flagging and validating the shared Ukrainian background. Examples 1 and 2 illustrate that English functions as a marker of one's feeling of already belonging to the Canadian community. The analysis also demonstrates that English is used in requests for financial assistance, or in medical emergencies (as example 4 below illustrates), as well as to highlight local contexts, specifically with respect to matters of local concern, such as searching for a job, a doctor, a store, or for advertising local events.

The Russian language in the posts and discussions studied is rarely attested. Consider example 3, which is a dating service advertisement in Russian followed by network participants' commentaries:

\section{3. [R] [Ukrainian dating service ad/text]}

(A) [U] And why is your Ukr dating in the Russian language?

(B) [thumbs-down emoji]

(C) [U] Good stuff, but first of all there should be Ukr and Eng as options.

In example 3, despite the use of Russian in the text of an advertisement, the commentaries following this ad are in Ukrainian. Speakers A and C clearly display their dissatisfaction with the fact that the Ukrainian dating site is in Russian and does not offer a choice of either Ukrainian or English. Moreover, the Russian language post in example 3 receives a "thumbs-down" emoji, that is, a "dislike" by speaker B (in addition to more thumbs-downs by other readers of this ad). In the data set, there is only one other Russian language advertisement: for work visas in Canada, which also demonstrates that Russian functions in advertisements. The work visas ad, similarly to example 3, received a number of thumbs-downs, which in the context of social media language practices demonstrates speakers' negative attitudes toward both the Russian language and the authors or posters of these ads. It may also be argued that advertisements are official and business texts, in which the use of a state language is expected. Therefore, Ukrainian as the state language of Ukraine, is being "requested" by participants.

\section{4. (A) [E] [an appeal by a female for help with her father's medical issue]}


(B) [U] Niushka, my entire family and I will support you and we hope for support of participants from this group.

(A) [R] Thank you, Natashen'ka.

In example 4, speaker A begins her appeal in English. Speaker B communicates in Ukrainian, and speaker A replies in Russian. The address forms in both example 4(B) and example 4(A) are diminutives of female names, signaling a closeness of these interlocutors and their familiarity with each other. As example $4(\mathrm{~A})$ is an appeal for help from the Canadian community, it is in English. Of interest is the use of both Ukrainian and Russian in example 4, by speaker B, who is an active participant in the group studied, and uses Ukrainian to address her friend. The friend, speaker A, replies to B in Russian. This example shows that Russian is used in "close" conversations between friends, who perhaps used to speak Russian earlier or most likely still do in face-to-face interaction, signaling the function of Russian as reverting to their first language. The Ukrainian used by speaker $B$ is the language of communication in this Ukrainian diaspora social network and is "on display," therefore showing the juxtaposition of Ukrainian and Russian, placing them into different spheres of interaction. This example supports Dailey-O'Cain's view that social media communication is inherently performative, and that identity work can be more visible in this context than in face-to-face interaction because "all identity work is to some extent less about who we essentially are and more about who we want to be to others and how others see us" (55).

In fact, conversation 4 represents an example of how language use in social media differs from language practices in off-line environments. In one of the interviews, a female Russian-speaking participant, Katia, notes that she uses English and Russian in daily dealings with family and at work, but uses Ukrainian predominantly on Facebook: "Well, most of my friends are Ukrainian. Therefore, [I communicate] in Ukrainian." Another female Russian-speaking participant, Ksenia, notes that she uses English predominantly on Facebook (although this was not attested to in the data studied). She reasoned that if she were to write in Russian "the Canadian side of [her] Facebook friends would not understand it and everyone in Donetsk ${ }^{18}$ understands English." During the interview, this participant noted her poor command of Ukrainian. Therefore, knowing that Russian is not the primary language of communication in the social group, the participant reverts to English, not her first language Russian. The choice of English might be made to accommodate English speakers, or as self-disassociation from Russian, especially because the participant uses English and not Russian to

18 The participant mentioned the city of Donetsk, her home town in Ukraine. This city is in the current war zone in Ukraine. 
communicate with her Russian-speaking friends in Donetsk. Katia, a Russian-speaking female, identifies both Russian and Ukrainian as languages she uses in everyday life. On Facebook, she reports using English with her Polish friends and mostly Ukrainian with "friends who are Ukrainians." This participant uses Russian in everyday communication with family and friends but does not use Russian on social media.

Ukrainian-speaking participants reported using predominantly Ukrainian on social media, which signals that their language practices online are similar to those in daily life off-line, unlike the Russian-speaking participants. One participant, Halyna, uses Ukrainian and, rarely, English, in Facebook communications (similar to everyday practices). Natalia uses both Ukrainian and English and notes that her choice depends on the interlocutor. Liuba reports using Ukrainian and English, but also "occasionally Russian, only to her Russian-speaking Ukrainians."

In the diaspora social media network under consideration, language choice and language use by Russian-speaking participants is of particular interest. As shown above, the use of Ukrainian is reported by Russian speakers and is displayed in social media interactions. This code-switching may be viewed as symbolic for the speakers who report on their use of Russian, and to some extent English, in everyday communication with families and friends. Such language practices by the Russian-speaking Ukrainian diaspora differ from Russian speakers in Ukraine, where language practices in social media normally mirror those in the off-line space (Kulyk, "Language Ideologies").

Example 5 displays further code-switching practices of the diaspora speakers in the social media network.

5. (A) [U] Thank you all, who visited our Ukrainian program in the library "[name]" today. It was our great pleasure to see some of you, with your kids, who came from other, distant, parts of the city. I am very happy that you visited us! I continue to hope what we, and more of us, will meet again in January :)

(B) [R] We also want to visit you in January. Is this possible?

(C) [U] Of course, this program is open to all those interested!!!

Example 5 is a post about a Ukrainian-language library program in a Canadian city for families with young children. Speaker A, who is the organizer of the program, communicates in Ukrainian. An interested participant B requests, in Russian, whether her family could participate in this Ukrainian-language program. Speaker C confirms in Ukrainian that everyone is welcome. In example 5, the Russian speaker B signals her wish to participate in a Ukrainian-language program, therefore, a desire for a potential code-switch into Ukrainian, while in Canada. 
This particular shift to Ukrainian, or desire for a shift, of Russianspeaking Ukrainians after immigrating to Canada, is attested to and supported by results obtained from interviews with the Russian-speaking participants in the study. One female Russian-speaking participant, Ksenia, discusses the languages used in her life as follows: Russian and English are used at home, occasionally mixing the two with her children; English is the language used at work; and both Russian and Ukrainian are used in communications with friends. She says that she learned Ukrainian only after arriving in Canada. Interestingly, with respect to her children, she informs that upon arrival in Canada her children attended a heritage Russianlanguage school. ${ }^{19}$ She notes that her children were overwhelmed with the volume of the school's curricula, and thus experienced difficulties in this school and eventually withdrew. She states "After all, let my children regain normalcy and let them learn English first, and only then they could study Ukrainian now." Ksenia wants her children to learn English before learning other languages. In the last part of this statement, Ksenia notes "Ukrainian now" as the language for her children, not their first language, Russian, and not the language in which they initially began schooling in Canada. During this interview, Ksenia says she "is trying to sign up [her] daughter for classes in the Ukrainian theatre." In addition, she notes that being a Russian speaker, she "code-switches immediately when [she] hears someone speaking Ukrainian." Ksenia shares her anxiety about her "russkoiazychnost"' (being a Russian-speaker) in the Ukrainian diaspora community. Nevertheless, she notes that when addressed in Ukrainian, she would reply in Ukrainian, signalling accommodating tendencies toward the language of the interlocutor. Ksenia also says that gradually she "began realizing that people are accepting of her linguistic background." Being a Russian-speaker who only in Canada began communicating in Ukrainian, she feels more secure speaking Ukrainian in the community and with Ukrainian-language speakers. As Ksenia's example illustrates, she and her family are positioning themselves as Ukrainians, and are accepting the Ukrainian language into their interactions with Ukrainian-speaking friends, as well as via their children.

A female Russian-speaking participant, Katia, when discussing her relationship with the Ukrainian community in Canada, touches upon the question of tolerance and intolerance of various languages and variants by groups in the diaspora. Conducting her conversation in Russian, she points out:

19 In this Canadian city there are several heritage language schools, which are normally run on Saturdays or Sundays. 
There used to be stereotypes about Ukraine, South being the Russianspeaking and West Ukrainian-speaking ... But Ukraine is now [different]. New generation of Ukrainians, contemporary people from various regions (of Ukraine) are all capable of speaking Ukrainian ... no barriers at all in this respect.

This response in the context of the discussion of this participant's contacts with the local Ukrainian community and attitudes toward the different languages and variants, signals Katia's attitude toward Ukrainian as the language that now could potentially be used by all Ukrainians. Moreover, being a Russian-speaker, she demonstrates her attitude toward a (possible) language shift in her understanding that a Ukrainian person, regardless of his/her first language, can interact in Ukrainian and desires to be proficient in a national language, Ukrainian in this case.

Interesting data are also received from another Russian-speaking participant, Taras, a single male in his late twenties. During the interview, when asked which language he speaks at home, Taras answers: "If [a Canadian city name] ${ }^{20}$ is considered home, then I speak Ukrainian, yes Ukrainian," signaling that for him Ukrainian is considered the new "home" language, which he reiterates twice. Note that during this interview, Taras reports that he speaks Russian with his friends. Specifically, with his Ukrainian-speaking friends he continues using Russian when his friends communicate in Ukrainian. This participant notes that regardless of this language choice, he and his Ukrainian-speaking friends "understand each other perfectly fine." Taras's claim that Ukrainian is now his "home" and his native language, is clearly an "ideal" or a symbolic display of the participant's shift in language ideology. It also shows how language practices and language attitudes have real-world consequences in this participant's life (as stressed by Pavlenko and Blackledge 12). Taras's view of the "native language" or "ridna mova," supports Friedman's discussion that "[u]nlike the English term, ridna mova does not necessarily refer to one's first language; rather, Ukrainians tend to use the term to refer to the language with which they most closely identify, which may be the result of personal associations ... or ethnic affiliation" (168). Bilaniuk and Melnyk also point out that "often people will designate as 'native' the language that corresponds to their ethnic heritage, even if they know it poorly, in the belief that this is how things should be" (346).

20 This city is the same as one in which the studied Ukrainian social network originated and is administered. 


\section{DisCoURSE ABOUT LANGUAGE AND LANGUAGE ATTITUDES}

In both the social media and the interview texts studied, the discourse about language is worthy of analysis. As demonstrated above, Ukrainian holds a special status in the studied community. In social media communication, Ukrainian is used as the default language and is central in those interactions (English and Russian are used to considerably lesser degrees). In everyday practices, Russian-speaking participants, albeit still using Russian predominantly with friends and family, attach certain new values to Ukrainian. They display a shift in their attitude toward Ukrainian, showing that they view Ukrainian as Ukraine's national language. Some participants suggest that they could, potentially, adopt Ukrainian as their native or "home" language. And for some participants, Ukrainian has already become the language used in certain environments.

Attitudes toward the Russian language were also noted. Specifically, participants' negative attitudes toward the use of Russian in the ads were discussed. It was noted that the participants expect the state language, Ukrainian in this case, to be used in official and business texts that originate in Ukraine. A different stance is taken with respect to language practices in social interaction. In social media, Russian albeit not very common overall, becomes apparent for its use between close friends. Similarly, with respect to everyday practices, participants report using Russian with friends and family. Importantly, in instances of participants' use of Russian in the network studied, or in everyday language practices of some Russianspeaking participants outlined above, this language choice is not criticized and is accepted in the community. As example 5B above illustrates, the network participants invite and welcome the Russian-speaking Ukrainians to join the Ukrainian-language local community and its activities. The example of Taras, the Russian-speaking participant, shows that he can use Russian with his Ukrainian-speaking friends with no obstacles. The Ukrainian-speaking Liuba says she occasionally speaks Russian to her Russian-speaking Ukrainian friends. These practices demonstrate language attitudes of inclusivity and tolerance of language choices in the community under consideration.

In the social media communications studied, discourse about language is not overtly represented. In the data set, only one example is relevant to the analysis. Consider example 6 (illustrated also in Figure 1):

6. (A) [U] Let your force be awakened! $:$;

(A) [U in image] Switch to Ukrainian! 


\section{Figure 1. "Switch to Ukrainian." 1}

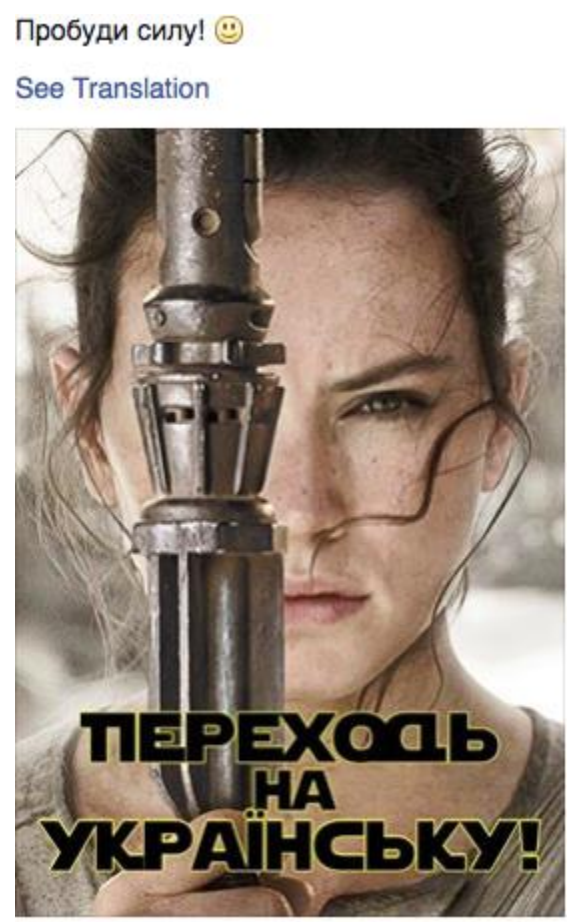

Example 6 and Figure 1 show an allusion to a recent Star Wars movie through an overt appeal to Russian-speaking Ukrainians to switch to Ukrainian. In the data set, this post received only five "likes" and no comments (unlike other comparable ads). And because "likes" in social network communications signal what is acceptable, important, and pertinent to participants, this meagre reaction may be explained by the fact that this appeal to switch to Ukrainian is not very relevant to the Ukrainian network studied. This online community has already accepted Ukrainian as their main language of communication, as shown above (in striking contrast to social networks in Ukraine which continue to display a truly multilingual interaction). The low number of "likes" might also underline the acceptance

21 This ad figured prominently on several Ukraine-based social media networks. There is a visible project in Ukraine, entitled "Perekhod' na ukrains'ku" ("Switch to Ukrainian"), with a Facebook page created in December 2015. As reported on this page, in seven and a half months from the time of its launch, the project gathered over fifteen thousand followers. As of September 23, 2017, the site reports 31,615 followers. 
of Russian-speaking Ukrainians into the community. Therefore, this example and those discussed above, strengthen the argument that Ukrainian is the primary language of interaction in the social network community studied and its primacy is not being debated, as example 6 suggests.

Discourse about language is particularly interesting based on interview data from both Russian- and Ukrainian-speaking participants. Only one Russian-speaking participant, Alina, expresses an overall indifferent position toward the language question. According to Alina, "people should speak whatever language they want and in whatever language they are most comfortable." The opinions of the other nine participants were very dissimilar. Four out of nine participants indicated that the language question was not important for them prior to arriving in Canada. Now, while in Canada, and because of the situation in Ukraine at the time of the participant interviews, the matter of language is on their minds, is pertinent to their lives, and they often talk about it. For instance, the Ukrainian-speaking participants Natalia and Liuba both stress the visibility of the Ukrainian language question in the Ukrainian community in Canada. They analogously note that although many Canadian Ukrainians are not proficient in the Ukrainian language, the matter of language and the idea of language preservation are there and are visible. These Ukrainian-speaking participants praise the Ukrainian diaspora for preserving the language and culture. The Russian-speaking single male participant, Taras, stresses the importance of Ukrainian for his future children. The Russian-speaking female, Ksenia, responding to the question of whether the language question is important for her, answers:

very (important) and from not long ago. All of my pride for some reason began. Because of the events that are taking place in Donetsk, I actually convinced my children that they speak Ukrainian. The word 'Russian' for me now is somehow [pause] ... Something hurts inside when I hear this word. Therefore, I try to avoid talking about it.

In Ksenia's answer, a very powerful language stance is voiced, especially by the fact that she convinced her Russian-speaking children that the language they speak is, actually, Ukrainian (i.e., calling the Russian language Ukrainian). Katia, the Russian-speaking participant, married without children, indicated that she uses English and Russian in everyday communication with her husband, her friends, and at work. When asked about the importance of the language question for her personally, she directs the discussion toward her family and potential children, elaborating that "the language is very important, and its preservation is paramount. In my case, I need to implement two languages [laughter], Polish and Ukrainian. Yes, this is very important." In this statement, Katia demonstrates her potential code-switching to Ukrainian with her future children. 
Bohdana, a Ukrainian-speaking female, at first states that she never thought about the language used while living in Ukraine: "we thought that we speak Ukrainian and, [pause] well, Ukrainian." But she states, after she arrived in Canada, "the entire world is somehow upside down." While discussing how the importance of the language question only occurred to her after arriving in Canada, Bohdana begins to remember how she feels "sorry for hearing Russian in Kyiv." She notes that it is sad "not to be able to hear your native 22 language in your own country" and that "Ukraine was swallowed by the Russian language." Bohdana stresses that "it is important to preserve your native language." She continues, "before I never thought that language could disappear somehow, right? But now I see that it could, yes, it could," displaying her attitude toward the language question and its importance in the context of the diaspora.

Halyna, a Ukrainian-speaking participant indicates that "the language question is particularly acute and relevant now." She overtly acknowledges her changing attitude during the last two years toward the UkrainianRussian language question "from very radical, to radically negative and to some sort of neutral" attitude. The language question, in her view, is a form of political manipulation, and during the last few years it became irrelevant. She acknowledges her tolerance toward speakers' choice of language, but notes that people living in Ukraine, in order to be proud citizens, need to learn Ukrainian. In her view, not knowing Ukrainian "is simply a taboo" in Ukraine. ${ }^{23}$

Liuba, a female Ukrainian-speaking participant, who is married and has children, notes the importance of the language question especially for her children. She wishes "that children will not lose Ukrainian and will pass it on to their own children and grandchildren," because although Ukrainian is used at home, Liuba's children already speak English with their peers. This participant also notes: "It is so nice to see a Canadian, who being a thirdfourth generation Ukrainian still speaks the language," and she wants her children to preserve the language. When asked whether the language question in Ukraine was important to her, she responds negatively, indicating that she learned both Ukrainian and Russian but did not really think about this as being an issue. A similar position is voiced by another

\footnotetext{
22 In examples here and elsewhere, in translating participants' use of "ridna mova," the term "native language" is used.

${ }^{23}$ With respect to language and the language question in Canada, Halyna notes that although she is impressed with the level of cultivation and preservation of the Ukrainian language, the language of the Ukrainian diaspora is archaic. According to Halyna, this "100-year old language is being taught in schools," the books that children are reading are "old-fashioned and unappealing to today's youth" and for her "this question is important and at the same time painful."
} 
female Ukrainian-speaking participant, Natalia, who hopes her children will preserve Ukrainian, noting that even after one year of study in the Ukrainian bilingual school, her child speaks English in school. This participant also praises the older waves of Ukrainian diaspora for preserving the language and culture to admirable heights. With respect to the importance of the language question in Ukraine, Natalia is even surprised by the question: "of course it was important! This is, after all, our native language. We live in Ukraine, therefore, what kind of questions may one have? This is obvious." In this statement, the participant clearly still associates herself with Ukraine, as if she was still living in it and being a part of the home country.

Sashko, a Ukrainian-speaking male, when discussing the importance of the language question, says that his attitude changed slightly after arriving in Canada. He notes that he remembers his language experiences in Ukraine and now realizes that hearing a different language is not necessarily negative. For him, a different language "is not good or bad, but different." To some extent, he accepts that both Ukrainian and Russian are spoken in Ukraine, but a lack of will to speak Ukrainian in Ukraine "still does not make sense" to him. Remembering his previous experiences, Sashko states: "With respect to Ukraine, I really liked when in conversation, Ukrainian was pure, and when it sounded pure, then it was beautiful. I love it, there you go." And especially in Canada, Sashko "feel(s) to what extent people care about preserving their heritage, their cultural heritage, and of course, the language." He says,

by being here, I realize that ... it is impossible to preserve own identity, own culture, own nation if you converse not in the language that belongs to your nation. This question is most likely fluid for us Ukrainians . . . I do understand that one language could be used at home and another in the street, but, if there is a choice, then I put my stakes on Ukrainian.

While Sashko's answers may seem a bit contradictory, they all indicate that the language question is of great importance to him and for his identity, especially in his new diasporic environment.

Iaroslav, another Ukrainian-speaking male, mentions that the language question has always been important to him. The language, according to Iaroslav, is the "keystone of nationality" and for him it was always central "to what extent people cherish their native language." He notes that he speaks both Ukrainian and Russian, and that he will speak to someone in Russian if he feels that that person respects him as a Ukrainian. Iaroslav also says, "if someone tells me that they do not understand Ukrainian [and they are from Ukraine], and I feel that they do not respect me, then I communicate exclusively in Ukrainian or English. Interesting attitude, right?" This positioning toward the language question and Iaroslav's code-switching in the scenario he outlines both signal the importance of the language question 
to him and his strong belief that every Ukrainian is capable of speaking Ukrainian, and that this language is to be cherished as a national symbol. Here Iaroslav demonstrates his ideological position toward Ukrainian being the national language of Ukraine. During the same interview, when Iaroslav discusses his participation in a community organization, he notes that there is no difference in which language they communicate: "we are from different parts of Ukraine, but we have one goal, one purpose; that is, we have our Ukraine there from Donetsk to Lviv." This last statement demonstrates Iaroslav's idea of a united Ukraine that goes beyond linguistic differences, as long as the idea of Ukraine and "Ukrainianness" is shared and fostered. Iaroslav's attitude demonstrates that although he feels strongly about one national language, supposedly known by all Ukrainians, tolerance toward other languages used by Ukrainians is acceptable, but only if they respect Ukrainians and consider themselves Ukrainians.

Language attitudes are also displayed through certain positioning of participants with respect to different languages, and this positioning signals certain associations or distancing. Two participants, Halyna and Natalia, declare proudly about their native language: "Ukrainian, unquestionably!" Sashko states, "Ukrainian, of course!" In these examples, "bezumovno" "unquestionably," and "zvychaino" "of course," are indexes that display participants' strong association with Ukrainian as their first and native language.

Bohdana, a Ukrainian-speaking participant, when asked about languages she knows, lists Ukrainian, Russian, and Polish. Interestingly, as she touches upon her proficiency in Russian later in the interview, she states: "and Russian, well I never have spoken, well, perhaps a few times. But this was mostly in Ukraine, usually some types of news, TV, cinema, etc." In this part of the interview, Bohdana signals her distancing from the language, in which she otherwise claims to be proficient.

Sashko, a Ukrainian-speaking male, when discussing his language practices, reports that his knowledge of both Ukrainian and Russian is at the same level of proficiency, "most likely similarly to any Ukrainian person." But he stresses: "I personally try, and probably have been trying for many years now, most likely twenty or so, not to use Russian." Such a statement clearly displays his disassociation from the Russian language.

Ksenia, the Russian-speaking participant, also voiced her distancing from associations with Russian. She notes, as discussed above, that she goes through negative emotions when hearing the word "Russian" and that she "tries to the best of her abilities to talk less about it." In fact, she reports on a powerful language positioning in their family: a Russian-speaking family, who while still using Russian, are shifting language practices toward using more English, convey to their children that they speak Ukrainian.

Taras, a Russian-speaking single male, notes: 
After arriving in Canada, because of the Ukrainian community and after what happened in Ukraine, I really want to establish myself more that I am in fact a Ukrainian. I am the carrier of my country's culture. And I would very much like for my children to be proficient in Ukrainian. If I stay in Canada, I want my children to have Ukrainian as their second language, not Russian. ${ }^{24}$

This participant also voices an interesting language attitude, specifically, his perception of one language that is common to all Ukrainians: "When I arrived here, I really felt like finding specifically Ukrainian community because when speaking the same language, it is much easier to understand each other and find a common language, right?" In this statement, Taras goes beyond the juxtaposition of Ukrainian or Russian, but rather delineates his idea of a common, pan-Ukrainian language of understanding; a language of commonality, as the language of "Ukrainianness." (As was noted above, this participant is predominantly Russian-speaking, with a desire for his future children to have Ukrainian as their second language, not Russian.) With respect to the Russian language, Taras continues: "Unfortunately, Russian could in fact be /[E]: beneficial/ /[U]: in a sense that/, in a sense that it is Russian nonetheless and many foreigners do converse in Russian." In this last sentence, when acknowledging the status of Russian as "beneficial" and also as an international language, Taras still expresses his distancing from Russian, which is also signalled by his intra-sentential code-switching to English and also to Ukrainian. Taras also displays his disassociation from the Russian language when talking about his friends. He notes that his friends are predominantly Ukrainians with whom he speaks both Ukrainian and Russian. He underscores, speaking in Russian: "The majority of my friends are Ukrainians. And with Russians I somehow do not cross any paths. And, honestly, I have no desire to do so ... After what happened, we Ukrainians and Russians are in fact different and it is important to /[U]: not forget/ about this." In this last statement, the disassociation from Russia and Russians, whom he juxtaposes to Ukrainians, is also signalled by this participant's code-switching to Ukrainian at the very end of the statement. Taras's phrase "after what happened" alludes to the Russian invasion of Ukraine. And the last statement demonstrates how the political events have triggered the increased salience of the national identity of Ukrainians, as noted by Kulyk ("Ukrainian Nationalism").

The analysis above demonstrates how a range of linguistic practices and resources, as discussed by Bucholtz and Hall contribute to the production of identities ("Identity," 598). As we can see, language practices, including language choice, code-switching, and discourse about language and language

\footnotetext{
${ }^{24}$ Here the participant implies that the first language would be English.
} 
attitudes, all contribute to participants' negotiations and renegotiations, as well as to the construction of identities in the diasporic context studied. The social network data and the interviewees' responses both amply demonstrate Pavlenko and Blackledge's ideas about the importance of studying "what identity options are available to speech event participants, what shapes these options, and which identities are being challenged and why" (10).

\section{DISCUSSION AND CONCLUSIONS}

In the foregoing, one diasporic community was studied with respect to its members' language practices in interactions online and off-line, as well as participants' attitudes and positioning toward a number of specific languages. In both social media communication and interviews, factors of linguistic code-switching, language choice, and language practices of participants were studied because they identify participants as belonging or not belonging to a particular community of practice. Additionally, the analysis of discourse about language was associated with participants' views on the importance of the language question, as well as their overall attitudes toward languages relevant to their lives. Here, specific attention was also paid to how participants position themselves with respect to specific languages, and how they display certain associations and disassociations related to these languages.

It was shown that Ukrainian figures as the primary and almost default language of communication in the social network studied. This language choice therefore indexes the community studied with the Ukrainian language and positions Ukrainian as the central language of the local community. In fact, such positioning of Ukrainian may be viewed as an assertion of a Ukrainian identity in the diasporic community studied, and an ideology of language use in the public space. This language practice may be viewed as a form of "language display" (Coupland 1) or "iconization of language" (Irvine and Gal 37), signalling a process of perhaps reUkrainianization of the studied community. In this community, being a Ukrainian-(Canadian) means using Ukrainian on display, that is, in the public space, and also having children learn Ukrainian, even though in some cases Russian is still used in communication with family and friends. It is interesting to note that for the Russian-speaking participants in the study, the interview data confirm that such code-switching to Ukrainian was not of interest to them while they were still living in Ukraine. The predominance of Ukrainian as the language of choice in social media interactions may be viewed as a process of reconfiguring this community's identification with Ukraine and also with their Ukrainian "selves." The results indicate that the 
Ukrainian language is a central and indispensable part of "Ukrainianness" in the diasporic community studied. In cases where participants reported a lack of proficiency in Ukrainian, they noted instead their use of English in social media communications, preferring it to their first language, Russian, thus signalling their disassociation from the Russian language and an acceptance of the new diasporic "self."

When discussing their language practices, the Ukrainian-speaking participants in this study asserted that Ukrainian was their first and native language, a language they use with family and friends. For Ukrainianspeaking participants, the language question was shown to be of great importance, especially in the new diasporic environment. Participants voiced their desires to preserve the Ukrainian language and reported fears of losing this language in an English-speaking environment. With respect to the Russian language, Ukrainian speakers displayed and reported their openness to either maintain sustained language choices (Ukrainianspeaking participants use Ukrainian and Russian-speaking participants use Russian in the same conversation), or code-switch to Russian in some instances to include Russian-speaking Ukrainians in the conversation. Some speakers rather proudly acknowledged their current positioning of tolerance toward other languages in the community (Russian in particular). At the same time, a vivid positioning with respect to the status of Ukrainian was also articulated. Specifically, according to some participants, every Ukrainian should be able to speak Ukrainian; the Ukrainian language is or should be the pride of all Ukrainians, and all Ukrainians need to respect their language. It is noteworthy that, to various degrees, the Russian-speaking participants supported these opinions. In the interviews, an interesting thread was also observed in that although the Ukrainian-speakers demonstrated their acceptance of Russian language use by Russian-speaking Ukrainians, they nevertheless showed strong disconnections or disassociations from Russia and the Russian language.

The majority of Russian-speaking participants also noted the acuteness of the language question in their own lives, and in the diaspora in particular. Some spoke about their emergent pride in speaking Ukrainian. Others, while noting their insecurities in speaking Ukrainian and low levels of language proficiency, nevertheless stressed that the language is important in their personal lives and especially in their family lives, and that their language practices are openly accepted in the community studied. One participant thought the language question was important, but not necessarily whether it is Russian or Ukrainian. He commented that Ukrainians have one common language that is shared by all Ukrainians, that is, a pan-Ukrainian language of understanding or the language of "Ukrainianness," the language of being Ukrainian that distinguishes Ukrainians from "others." This pan-Ukrainian language of understanding is clearly an idealized situation. The results of the 
study demonstrate that the Ukrainian language is not the self-evident and common language of understanding in Ukraine or among Ukrainians because, as noted above, some recent immigrants from Ukraine have a low proficiency in Ukrainian.

The analysis proved particularly interesting with respect to the Russianspeaking participants of the study, and their "real" and "ideal" codeswitching. The "ideal" or symbolic code-switching was seen when one Russian-speaking participant declared Ukrainian to be his "home" language, while acknowledging that he used Russian in his daily communication. An "ideal" code-switching was also reported by other Russian-speakers: one female participant who convinced her Russian-speaking children that the language they speak at home is, in fact, Ukrainian; another female participant who wanted her children to learn English first and then Ukrainian; yet another female participant who wished her future children to know two languages, English and Ukrainian; and a male participant who wanted to establish himself as "more Ukrainian" and for his future children to be proficient in Ukrainian.

"Real" code-switching was observed in interactions online, when for some Russian-speakers Ukrainian became the language of communication in the online diasporic community (a female participant expressed a wish to join the Ukrainian-language children's book club). Therefore, the analyzed code-switching, or the acceptance of Ukrainian by Russian-speaking Ukrainians either via their children or in their language practices, in reality or symbolically, displays "how languages are appropriated in construction and negotiation of particular identities" (Pavlenko and Blackledge 10). In particular, the code choice of Ukrainian or the code-switch to Ukrainian, is used by the speakers as a powerful tool to position the "self" as Ukrainian, to index associations with Ukraine, locating the "self" in the diasporic community, demonstrating the positionality and indexicality principles in Bucholtz and Halls's framework ("Identity," 585, 592, 594). This language choice, or its switch, becomes a powerful tool for accepting the new "self" and rejecting any possible association with Russia (Putin's Russia in this case). Therefore, a new "self" emerges, showing identity as "the emergent product rather than the pre-existing source of linguistic and other semiotic practices" (Bucholtz and Hall, "Identity," 588). In addition, the switch to Ukrainian by Russian-speaking Ukrainians adheres to what Bucholtz and Hall call distinction, a concept that "focuses on the identity relation of differentiation," in which language "is an especially potent resource for producing it [distinction] in a variety of ways." The switch to Ukrainian is a suppression of any similarities to Putin's Russia "that might undermine the construction of difference" ("Identity," 600).

As shown in the foregoing social media communications, participants displayed their disassociations with Russian via negative reactions to the 
Russian-language ads in the communication network. During the interviews, specifically the Russian-speaking participants conveyed their desire to disassociate from Russia or Russians. For one participant, it was painful to talk about Russia and any Russian matters; thus she avoided doing so. Another participant overtly stated his wish to establish himself as "more Ukrainian" and as a carrier of his own Ukrainian culture, while distancing himself from Russians, with whom he did not want to "cross any paths." As Bucholtz and Hall note, "identities are never autonomous or independent but always acquire social meaning in relation to other available identity positions and other social actors" ("Identity," 598). Therefore, the analysis illustrated the relationality principle of Bucholtz and Hall's framework which states: "identities are relationally constructed through several, often overlapping, aspects of the relationship between self and other, including similarity/difference, genuineness/artifice and authority/delegitimacy" ("Identity," 585). The fifth principle of Bucholtz and Hall, the partialness of identity, was also seen in texts analyzed. Specifically, "[b]ecause identity is inherently relational, it will always be partial, produced through contextually situated and ideologically informed configurations of self and other" ("Identity," 605-06). This partialness of identity was shown at the domain of language via language choice and code-switching, and through various associations of "self," and the positioning of "self," and disassociations from the "other" in the contexts studied.

Overall, the observed code-switching, language choice, and language practices, as well as discourse about language in general, were seen as resources employed by the speakers to create closer associations with the Ukrainian community and with being recognized as a Ukrainian, stressing the "Ukrainianness" of the "self." Simultaneously, participants displayed their disassociation with Russians, Russian matters, and to some extent with the Russian language, thus demonstrating how language attitudes and practices relate to the ideological positioning of the participants. The analysis also demonstrated a dynamic view of identities "with individuals continuously involved in production of selves, positioning of others, revision of identity narratives, and creation of new ones which valorized new modes of being and belonging" (Pavlenko and Blackledge 19). Identities are therefore constantly (re)shaped and (re)negotiated in interactions and through various linguistic resources, language practices, and language attitudes. 


\section{Works Cited}

Androutsopoulos, Jannis. "Multilingualism, Diaspora, and the Internet: Codes and Identities on German-Based Diaspora Websites." Journal of Sociolinguistics, vol. 10 , no. 4, 2006, pp. 520-47.

---. "Networked Multilingualism: Some Language Practices on Facebook and Their Implications." International Journal of Bilingualism, vol. 19, no. 2, 2015, pp. 185205.

Angouri, Jo. “I'm a Greek Kiwi': Constructing Greekness in Discourse.” Journal of Language, Identity and Education, vol. 11, no. 2, 2012, pp. 96-108.

Appadurai, Arjun. Modernity at Large: Cultural Dimensions of Globalization. U of Minnesota P, 1996.

Auer, Peter. Code-Switching in Conversation: Language, Interaction, and Identity. Routledge, 1998.

Bartram, David, et al. Key Concepts in Migration. SAGE, 2014.

Bilaniuk, Laada. "The Construction and Disruption of Ukrainian and Russian Languages in Social Media Discourses." Canadian Congress for Humanities and Social Sciences, CAAL National Conference, 28 May-1 June 2016, University of Calgary. Conference Paper.

Bilaniuk, Laada, and Svitlana Melnyk. "A Tense and Shifting Balance: Bilingualism and Education in Ukraine." International Journal of Bilingual Education and Bilingualism, vol. 11, 2008, pp. 340-72.

Bucholtz, Mary, and Kira Hall. "Finding Identity: Theory and Data." Multilingua Journal of Cross-Cultural and Interlanguage Communication, vol. 27, 2008, pp. 151-63.

---. "Identity and Interaction: A Sociocultural Linguistic Approach." Discourse Studies, vol. 7, nos. 4-5, 2005, pp. 585-614.

Cheskin, Ammon. "Russian Speaking (Non)identities in the Post-Soviet Space." RIDRU Seminar Series, 16 May 2017, University of Alberta. Lecture. http://ridru.artsrn.ualberta.ca/2017/05/18/ammon-cheskin-russian-speakingnonidentities-in-the-post-soviet-space/. Accessed 29 May 2018.

Coupland, Nikolas. "Bilingualism on Display: The Framing of Welsh and English in Welsh Public Spaces.” Language in Society, vol. 41, 2012, pp. 1-27.

Dailey-O'Cain, Jennifer. Trans-National English in Social Media Communities. Palgrave Macmillan, 2017. Series on Language and Globalization.

Das, Ranjana, and Pavlíčková Tereza. "Is There an Author Behind This Text? A Literary Aesthetic Driven Approach to Interactive Media." New Media and Society, vol. 16, no. 3, 2014, pp. 381-97.

"Facebook Users in the World." Internet World Stats, 4 Dec. 2017, https://www.internetworldstats.com/facebook.htm. Accessed 25 Mar. 2018.

Friedman, Debra A. "Our Language: (Re)imagining Communities in Ukrainian Language Classrooms." Journal of Language, Identity \& Education, vol. 15, no. 3, 2016, pp. 165-79. 
Goodman, Bridget. "Comparing Language Policy and Governance in Ukraine and Kazakhstan.” RIDRU Seminar Series, 18 Apr. 2017, University of Alberta. Lecture. http://ridru.artsrn.ualberta.ca/2017/04/18/dr-bridget-goodman-comparinglanguage-policy-and-governance-in-ukraine-and-kazakhstan/. Accessed 29 May 2018.

Heller, Monica. Codeswitching, Anthropological and Sociolinguistic Perspectives. Mouton de Gruyter, 1988/2010.

---. "Code-Switching and the Politics of Language." One Speaker, Two Languages, edited by Lesley Milroy and Pieter Muysken, Cambridge UP, 1995, pp. 158-74.

---. "The Politics of Codeswitching and Language Choice." Journal of Multilingual and Multicultural Development, vol. 13, nos. 1-2, 1992, pp. 123-42.

Hinther, Rhonda, and Jim Mochoruk, editors. Re-Imagining Ukrainian Canadians: History, Politics, and Identity. U of Toronto P, 2011.

Hryniuk, Stella, and Lubomyr Luciuk, editors. Multiculturalism and Ukrainian Canadians: Identity, Homeland Ties, and the Community's Future. Multicultural History Society of Ontario, 1993.

Irvine, Judith T., and Susan Gal. "Language Ideology and Linguistic Differentiation." Regimes of Language: Ideologies, Polities and Identities, edited by Paul V. Kroskrity, School of American Research Press, 2000, pp. 35-83.

Karim, Karim H. "Mapping Diasporic Mediascapes." The Media of Diaspora, edited by Karim, Routledge, 2003, pp. 1-17.

Kaye, V. J. "Foreword to the First Edition." The Ukrainian Canadians: A History, 2nd ed., by Michael H. Marunchak, Ukrainian Academy of Arts and Sciences, 1982, pp. 7-13.

Kozachenko, Ivan. "ICT and Migration." Horizon Scanning Report, 2013, http://2plqyp1e0nbi44cllfr7pbor.wpengine.netdnacdn.com/files/2013/01/ICT-and-Migration-Kozachenko.pdf. Accessed 20 Aug. 2017.

---. "Retelling Old Stories with New Media: National Identity and Transnationalism in the 'Russian Spring' Popular Uprisings." East/West: Journal of Ukrainian Studies, vol. 4, no. 1, 2017, pp. 137-58.

Kulyk, Volodymyr. "Language Ideologies in the Era of Facebook: Ukrainian SocialNetwork Discussions within and across Borders." Canadian Institute of Ukrainian Studies Seminars, 11 May 2016, University of Alberta. Lecture.

---. "National Identity in Ukraine: Impact of Euromaidan and the War." Europe-Asia Studies, vol. 68, no. 4, 2016, pp. 588-608.

---. "Ukrainian Nationalism since the Outbreak of Euromaidan." Ab Imperio, vol. 3, 2014, pp. 94-122.

Luciuk, Lubomyr, and Stella Hryniuk, editors. Canada's Ukrainians: Negotiating an Identity. U of Toronto P, 1991.

Lynn, Susanna Mairin. "Ethnic Identity Discourses of Recent Ukrainian Immigrants to Canada: Interactions between New Ukrainian-Canadians and the Established Ukrainian-Canadian Diaspora." MA thesis, University of Alberta, 2014.

Martynowych, Orest T. Ukrainians in Canada: The Formative Period, 1891-1924. Canadian Institute of Ukrainian Studies P, 1991.

Mavroudi, Elizabeth. "Diaspora as Process: (De)constructing Boundaries.” Geography Compass, vol. 1, no. 3, 2007, pp. 467-79. 
"Nabrydlo chekaty: chomu 65\% ukraintsiv hotovi emihruvaty v inshi krainy." Obozrevatel'ua, 14 Sept. 2016, https://www.obozrevatel.com/ukr/news/48075-nabridlo-chekati-65ukraintsiv-gotovi-emigruvati-v-inshi-kraini.htm Accessed 25 Mar. 2018.

Nedashkivska, Alla. "Symbolic Bilingualism in Contemporary Ukrainian Media." Canadian Slavonic Papers, vol. 52, nos. 3-4, 2010, pp. 351-72.

Norris, Sigrid. Identity in (Inter)action: Introducing Multimodal (Inter)action Analysis. De Gruyter Mouton/Trends in Applied Linguistics, 2011.

Pavlenko, Aneta, and Adrian Blackledge, editors. "Introduction." Negotiation of Identities in Multilingual Contexts, edited by Pavlenko and Blackridge, Multilingual Matters, 2004, pp. 1-33.

"Perekhod' na ukrains'ku." Facebook, https://www.facebook.com/pg/perehodnamovu/community/?ref=page intern al. Accessed 30 May 2018.

Petryshyn, Roman W. "Is There a Need and Opportunity for a New Research Focus on Canada Ukraine Relations?" Canadian Institute of Ukrainian Studies/Kule Centre for Ukrainian Canadian Studies Series, 22 Aug. 2017, University of Alberta. Lecture.

---. "Toward a Framework on Voluntary Pluralism: Five Contemporary Lessons on Community Development Taken from Ukrainian Canadian History." Yesterday, Today, Tomorrow: The Ukrainian Community in Canada, edited by Jaroslav Rozumnyj, Ukrainian Academy of Arts and Sciences, 2004, pp. 17-43.

Rampton, Ben. Crossing: Language and Ethnicity among Adolescents. Longman, 1995.

Seals, Corinne A. "Post-Maidan Language Politics in Ukrainian Diaspora Communities." The Language and Culture in Post-Maidan Ukraine: Transformations at Work," RIDRU Conference, 27-28 Oct. 2016, University of Alberta. Conference Paper. http://ridru.artsrn.ualberta.ca/2016/09/23/language-and-culture-in-postmaidan-ukraine-transformations-at-work-and-higher-education-reform-inpost-maidan-ukraine/. Accessed 29 May 2018.

Shuval, Judith T. "Diaspora Migration: Definitional Ambiguities and a Theoretical Paradigm." International Migration, vol. 38, no. 5, 2000, pp. 41-57.

Tsagarousianou, Roza. "Rethinking the Concept of Diaspora: Mobility, Connectivity and Communication in a Globalized World." Westminster Papers in Communication and Culture, vol. 1, no. 1, 2004, pp. 52-65.

Tsaliki, Liza. "Globalization and Hybridity: The Construction of Greekness on the Internet." The Media of Diaspora, edited by Karim H. Karim, Routledge, 2003, pp. 162-76.

Valenzuela, Sebastian. "Unpacking the Use of Social Media for Protest Behaviour: The Roles of Information, Opinion Expression, and Activism." American Behavioral Scientist, vol. 57, no. 7, 2013, pp. 920-42.

van Dijck, José. "Facebook and the Engineering of Connectivity: A Multi-Layered Approach to Social Media Platforms." Convergence: The International Journal of Research into New Media Technologies, vol. 19, no. 2, 2012, pp. 141-55.

---. "You Have One Identity': Performing the Self on Facebook and LinkedIn." Media, Culture and Society, vol. 35, no. 2, 2013, pp. 199-215. 
Vesela, Hanna. "Pereselyty sebe: chomu emihratsiia zalyshaiet'sia vichnoiu ukrains'koiu problemoiu." PolitekA, 11 Feb. 2017, https://politeka.net/ua/reading/analytics/405455-pereselit-sebya-pochemuemigratsiya-ostaetsya-vechnoj-ukrainskoj-problemoj/ Accessed 25 Mar. 2018. Virinder, S. Kalra, et al. Diaspora and Hybridity. SAGE, 2005. 


\section{Appendix: Interview Questions}

1. DEMOGRAPHIC INFORMATION

- Indicate whether the participant is a man or a woman.

- $\quad$ Age at time of interview.

- Were you born in Ukraine? Which region/city?

- Where did you live in Ukraine if different from your birth place?

- What is your current occupation?

- What was your occupation in Ukraine?

- Are you married/single/divorced/separated?

- Do you have children? If yes, how many?

- When did you/your family immigrate to Canada?

2. Language Practices

- Do you speak/read/understand any languages other than English? Which ones?

- How would you rate your proficiency in the languages you know? Russian? Ukrainian? English?

- Which language(s) do you use at home (with your children, your spouse, other members of your family)?

- Which language(s) do you use at work?

- Which language(s) do you use when communicating with your friends?

- How would you describe your proficiency in these languages?

- Who are your friends? (i.e., Ukrainians, Russians, Canadians, others)

- $\quad$ Are there many recent immigrants in your circle of friends?

- Which language(s) do they speak?

- Do you participate in any social media networks? If yes, which language do you use?

3. IMPORTANCE OF LANGUAGE QUESTION

- Is the question of language important to you? Why yes or why not?

- Was it important for you in Ukraine? 
4. EXPERIENCE IN CANADA

- Which (cultural) activities do you attend as a family?

- Which extracurricular activities do your children do? Which programs do they attend?

- Which school do your children attend?

- How do you view the local Ukrainian community?

- What would you say is important to you as a Ukrainian-Canadian or a member of the Ukrainian community?

- How do you interact with the local Ukrainian community? Do you feel part of it? Do you feel "at home"? Why yes or why not?

- Do you participate in any Ukrainian social network communities?

- $\quad$ Do you take part in the life of the local community? If yes, in what ways? How would you want to participate?

- What do you think characterizes the Ukrainian diaspora to other Canadians? Is it organizations, activities, community, culture, language or other?

5. ABOUt UKRAINE

- $\quad$ Do you maintain ties with Ukraine?

- What do you miss most about Ukraine?

- Which three words come to mind when you hear the word "Ukraine" and "a Ukrainian"? 